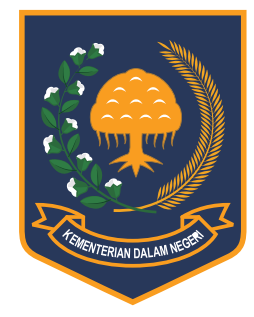

Jurnal Bina Praja 9 (1) (2017): 101-114

Jurnal Bina Praja

e-ISSN: 2503-3360 | p-ISSN: 2085-4323

Accreditation Number

735/AU2/P2MI-LIPI/04/2016

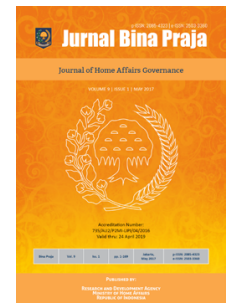

http://jurnal.kemendagri.go.id/index.php/jbp/index

\title{
Pathology Bureaucracy: REALITY OF THE INDONESIAN BUREAUCRACY AND PREVENTION
}

\author{
Lesmana Rian Andhika * \\ Department of Administration Sciences Faculty of Social and Political Sciences \\ Padjadjaran University \\ Jl. Bukit Dago Utara No. 25 Bandung 40135
}

Received: 6 February 2017; Accepted: 29 April 2017; Published online: 31 May 2017

DOI: $10.21787 /$ jbp.09.2017.101-114

\begin{abstract}
The performance of a bad bureaucracy indicates a bureaucracy is riddled with problems; a pathology which arose not always coming from outside the bureaucratic body, but pathology that has been flourishing and will be exerting influence when the bureaucracy is unhealthy. This research article would like to give an overview of the incidence of the pathological bureaucracy which argumentation pathology can prevent. The phenomenon occurs that the bureaucracy could not deliver good public services and bureaucracy is a den of disease. The specific purpose of this research is focused on finding ways of preventing the pathology of the bureaucracy that comes from a variety of scientific literature. The method in this research article is systematic reviews technique that tries to identify all the written evidence exists regarding research themes. The results of this study reveal that the pathology of the bureaucracy is something to be prevented if we want the bureaucracy to run the task properly, one of the ways that can be done is to do a bureaucratic innovation (an innovation on structure, systems, culture). The innovation of bureaucracy will not only make changes to the organization to prevent the pathology of the bureaucracy but also as an ingredient to do discretion for a government policy especially regional government.
\end{abstract}

Keywords: Pathology, Bureaucracy, Innovation, Preventing

\section{INTRODUCTION}

The activities of government organizations are often referred to with the bureaucracy in charge to resolve social problems that exist in society and also as the executor of any decision in the political process (Gailmard \& Patty, 2012; Goodsell, 2015). While someone is always talking about the bureaucracy, so the first impression of the public has envisaged an organization that is ugly, convoluted, and some of the arguments described by Rose-Ackerman (1999); Shi \& Temzelides (2004) is that the bureaucracy is a nest of corruption. The proper functioning of the bureaucracy realistically will determine the "color" of the nation and State life, if the performance of the bureaucracy is healthy, productive, creative, innovative, then so are the country and the society. If the bureaucracy is not good, then the bureaucracy can be a "predator" and can be detrimental to society in receiving good service. The existence of bureaucracy is a chain of liaison between the state and its citizens to provide good public service to the community, in which public services are just some of the manifestations of bureaucracy. However, the pathology of the bureaucracy continues to and endless from the time to time, almost every year the government takes the time to think about how to prevent the pathology of the bureaucracy that has always incited the unjust society.

The success of the bureaucracy to deliver good public service to the community is not only supported by the good organization of the pattern, the institution that is free from corruption, collusion, and nepotism, but human resource quality is worth to be considered seriously. The consideration that may affect the ability of the human resources, in addition to environmental factors, knowledge, use, and mastery of technology, is a cultural factor. The internal culture of an area will affect the morale and performance of each individual (Smith, 2001).

\footnotetext{
* Corresponding Author

Phone : +62 81310785785

Email : lesmana15001@mail.unpad.ac.id
} 
Paternalistic teaching is taught to treat people by family and loyalty. The nature of a familistic-localistic will appear larger than on the social value that is displayed by the bureaucratic apparatus may alone in opposition and showing personal enjoyment of the values of the organization. Injustice, partiality, and boxing (tribal, social groups) that serve the community will potentially cause problems as they undermine the Ministry, collusion, and the tendency of the occurrence "pungli" (illegal collection). This problem was identified by Caiden as "unfairness" and as pathology of the bureaucracy, which will touch the institution's service providers directly related to the public administration such as population, healthy institutions, and so on.

The nature of a familistic-localistic distinguishing the recipient of services that is not fair (unfairness) for various reasons will create a bureaucratic impression that the institution is convoluted, riddled with problems that will affect the performance of the bureaucracy. This is evidenced by some data and facts as reported by the Ombudsman of the Republic of Indonesia by 2015. It reported that nationally there was 6,859 reports/ public complaints by 2015 , as many as $41.59 \%$ or 2,853 reports, complaints of public service in local government institutions (Ombudsman RI, 2016). As another report to compare the data of Ombudsman institution related to the Republic of Indonesia in local government, reported the results of the performance evaluation of organization of local governance (EKPPD) against the report of the organization of the local governance (LPPD) of the Ministry of the Interior, there are 3 provinces, 10 counties, and 10 cities with the best performance for 3 consecutive years from 34 provinces, 416 districts, 98 cities, in Indonesia on April 25, 2016 in Kulon Progo, Province of Daerah Istimewa Yogyakarta (Kemendagri, 2016).

As a complementary data, by 2016 report from the Ministry of Empowerment State Apparatus Reform about the results of the evaluation of the implementation of the reform of the bureaucracy, accountability and Integrity at the district/city nationwide, presents the results of the evaluation of the value of the data category AA (0), A (1), BB (7), B (30), CC (168), C (231) and D (67). From the above data, it gives s serious thought to us on why the community complained about public service and as the results the Ministry of Empowerment State Apparatus Reform did an evaluation of a dominant on category $\mathrm{C}$ and category $\mathrm{D}$ even also still exists. The reason, the above data gives an overview of the more handling need to make government institutions better again.

So far, several studies conducted focused on the bureaucracy aspects of pathology and aspects of prevention. The author takes research and comparison of the relevant scientific literature. The first aspect, the study of Eyre (2011); Amadi \& Ekekwe (2014) stated that the characteristics of bureaucracy can affect the performance of the Organization and Government corruption. Moyo (2014) study stated that a great political influence in the bureaucracy allows a chance in increasing the level of corruption. Study Pinho \& Sacramento (2015) stated that the implementation of bureaucracy always shows patrimonial traits with the emergence of groups which has the authority and power to determine public officials. The second aspect, the study by AlQahtani (2013) is the innovation on structure, focusing on the changing structure of the bureaucracy to improve the performance of the bureaucracy. Tahmer (2013) mentions innovation in the system, such as the reform of the bureaucracy as the means to achieve change focusing on institutional aspects of governance and human resource issues. AlKhatib (2013) said that information technology utilization (e-government) could facilitate the public to get public services and community information services quickly and accurately.

Bottom line, there are many approaches applied to the research discussing the pathology of the bureaucracy and the way of prevention, the evidence that is presented in general is not much different, that the source of pathology which crawled on the bureaucracy derives not only from the external but also from the internal of the bureaucracy itself. Some of the arguments stated bureaucratic difficulties (government organizations) innovating became one of the reasons is that the bureaucracy is not functioning properly (Alberti \& Bertucci, 2007; Goodsell, 2015). The inability of the bureaucratic catch changes as well as the cause of the onset of torpor, the convoluted procedure, and the uncertainty of service (Dwiyanto, 2015). Making a rational choice is not easy and can be done, we do not reject the modernization but not necessarily be all at one thing that has long been in effect ignored it outright, it needs every effort to give you the ability to change the bad to get better.

This research seeks to contribute knowledge with exploring the pathology of the bureaucracy, the article in the study also tried to bring the concept of preventive pathology bureaucracy stemming from a variety of scientific literature. The difference lies in the problem of unfairness as the pathology of bureaucracy especially in bureaucratic apparatus and interaction between the communities. The purpose of this research was also to reaffirm its position with that of the bureaucracy that is not good is the nest of a wide range of pathology of the bureaucracy. The problem is whether the pathology of the bureaucracy can be prevented. 


\section{METHOD}

The method used in this research article is systematic reviews technique. (Gough, Oliver, \& Thomas, 2012) gave a view that a research can be understood as a systematic investigation to develop theories, establish evidence, and solve problems. The research could give understanding, develop a theory, put forward the facts, and find a way to solve a problem. Systematic reviews also give a great contribution to provide answers to the research (Harriss-White, 1997)(Petticrew \& Roberts, 2009).

The process of conducting a systematic review of the research follows the steps outlined by Petticrew \& Roberts (2009, pp. 248-287), 1). Define the question; 2) Consider drawing together a steering or advisory group; 3.) Write a protocol and have it reviewed; 4) Carry out the literature research; 5.) Screen the references; 6.) Assess the remaining studies against the inclusion/exclusion criteria; 7.) Data extraction; 8). critical appraisal; 9). Synthesis of the primary studies; 10 .) Consider the effects of publication bias, and other internal and external bias; 11.) Writing up the report; 12.) Wider dissemination. The above step is not just looking for different sources of literature but rather to the ability to search the relevant literature sources are expensive, require expertise, time and even money. This method also tried to define systematically to develop new concepts or theories. Systematic reviews are seeking to identify all the written evidence exists regarding research themes. Each method has a "positive and negative" in the study so that readers can assess for all the proof that there is such evidence to support or refute the hypothesis.

Unlike with traditional literature reviews, a research is often formed with the opinion piece, or "expert opinion", which is less useful and less contributive to the information debate research issues, this is caused by a number of factors and tends to be "biased" and conducted with the viewpoint that collect and interpret particular literature (Torgerson, 2003). The traditional literature review is still useful at the undergraduate level, for postgraduates are not too informing debate (Jesson, Matheson, \& Lacey, 2011). The reason this method chose as a preliminary study (preliminary research) is to understand the symptoms that develop in the field caused by the pathology of the bureaucracy. The data library is also a reliable tool in answering the research question. The empirical data is information that has been published by other people in scientific journal, magazine, or bookshaped that can enrich the study, which finding a way or developing the latest ways in answering the question of research.

\section{RESULTS AND DISCUSSION}

\section{A. Conceptual Framework}

\section{1) Bureaucracy}

The concept of bureaucracy was presented by M. de Gourney, by letter dated July 1, 1764, are written by Baran de Grim refers to the idea that complaining about government Gourney serving himself. De Gourney mention self-serving is a disease which he called with bureau mania (Albrow, 2005). Since other disciplines have adopted the emergence of the idea of de Gourney, bureaucratic term, widely adopted in the political dictionary in Europe during the 18th century. One of the works that influenced the bureaucracy in the world, the work of Max Weber (1921) entitled bureaucracy, Weber believed that administrative processes in government activities would only be efficient, routine and participants while the government designed in such a way, and it resembles a machine.

Weber understood and reminded from the early potential-potential problems that might come up. The characteristics of bureaucracy Weber spread on the public and private sector as adapted by Johnston (1993); Caiden (2009) as specialization, hierarchy, rules and regulation, management by administrators, impersonality, careerism. Garston (1993); Clegg (1997); Diefenbach \& Todnem (2012) explains in general, the bureaucracy characterized the existence of organizational structure characterized by a hierarchy specified by the applicable rules. Very easily can then understand, why there are the characteristics of bureaucracy? Simple answered that characteristics it is not another way of working that could embody certain values, such as efficiency, a clear process, fairness, certainty and standard results. The emergence of the thought provoking post-bureaucracy initiate thought that tries to break down bureaucratic shortcomings Weber. Thoughtprovoking post-bureaucracy put more effort into looking model modern bureaucracy that is more flexible and can be adapted to the environment, not to think of the hierarchy that is too long, convoluted procedures can hamper the pace of service, leading to the centralization of power by Robert Michels (1911-1962) which he described as an oligarchy. Tolbert (2010) adapt the words of Robert Michels, of typical evolutionary processes in the governance of the political organizations, and the impact of such processes on organizations ' goals, is very relevant to scholars of social movements. Bureaucracy just made the game of political elites, they try to influence the activities of the bureaucracy just for political expediency, the rest of the bureaucratic apparatus and resources just be game exploitation for political elites, and may not be able to create a good government governance. 
Kernaghan (2000, p. 93) giving his views, post-bureaucratic model has become well known to the public administration community, especially over the past decade. They include partnerships, empowerment, restructuring, re-engineering, information technology, and continuous learning. Very different from the characteristics of bureaucracy that is delivered by Weber, these traits will culminate in public service values (Kernaghan, 2000; Parker \& Bradley, 2004; Budd, 2007). Never the less Presthus (1961) assume the concept of bureaucratic Weber who make assumptions about human motivation is not necessarily matched by a non-western. Although the administration's experts in developing countries assess the importance of the change from a traditional bureaucratic red tape towards practical, examples of cases in developing countries such as India, Eastern Europe, Latin America, Africa, the Middle East that many found in the scientific literature. The bureaucratic ideal is very hard to do because the concept of a rational human being is very limited, there is nothing that can make rationally be perfect and even there is only rational bureaucracy ideal type is limited, it will be difficult to be realized (Simon, 2007; Bendor, 2010; Dwiyanto, 2015). Bureaucracy such as the two currencies that has different sides have the goodness and malice. A corrupt bureaucracy is a bureaucracy that is not pliable, rigid bureaucratic rules that bind, at the time of modernization truly is impossible to develop a bureaucracy that is pliable and can be developed following the demands of the public, civil society, economic systems, and environmental changes.

Clegg (1997, p. 181) calls, where the modernist organization was premised on technological determinism, the postmodernist organization is premised on technological choices made possible through ' de-dedicated ' compatible equipment. The organization of the future will prefer technology to help the work of the organization itself. The aim to facilitate providing information and simplify procedures, creating transparency. The application of electronics in the activity upon a surefire strategy for the government is how the country responsible for the guarantee and provide good service. IGI (2016), replied modernization techniques to improve the performance of bureaucratic programs and agencies, modernization is compulsory to change a variety of bureaucratic performance techniques and the latest ways and adapt to the development of the modern era.

Farazman (2009, pp. 5-6) give a perspective of the theory of bureaucracy consists of 1). View the use positively machinery bureaucracy of government; 2). Perspective views bureaucracy in negative terms; 3). Perspective on bureaucracy is a more realistic and more balanced one. Although the Weberian bureaucracy is outdated and reaps a lot of criticism. Argyriades (2010) recommends that the bureaucracy does de-bureaucratization. Osborne \& Gaebler (1993) also advocated emulating privatized bureaucracy of principles private. This argument seems to be the answer to the problem now faced by the bureaucracy that failed to finish and endless, various problems is not just caused by humans, the environment, but the narrow rule also is bureaucratic when threats evolve into the impossible. Bureaucratic position between one place and the other place is not the same, for example, they work in service of the fire department or agency that are more technical, procedure, and requires strict specialization, because their jobs demanded discipline and skills more, and very different treatment of people working in the service of cleanliness which only requires skills in cleaning something.

The core essence of the above description, the bureaucracy is representative of government activities. Niskanen (2007, p. 23) argue, the original use of the term, I understand, referred to a cloth covering the desk (the bureau) of eighteenth-century French officials, and the term soon became used to identify a form of government ruled by officials. A term used to identify the form of Government ruled (hierarchy) by officials. Pierre, (1995); Mill, (2001); Albrow, (2005); Farazman, (2009) mentions this activity is a form of an essence of bureaucracy.

\section{2) Pathology Bureaucracy}

Classify the dysfunctional and bureaucratic inefficiency is called bureau pathology. Bureaucratic diseases caused by a few things, the characteristics of the Weber bureaucracy is not working well (dysfunctional) which causes the disease bureaucracy even the term "red tape" is a criticism of the inefficiency of government organization (Bozeman, 2000). Red tape will affect several dimensions of work in a way surprising that depends on the subject known as stakeholders of the bureaucracy (Brewer \& Walker, 2010). Problems characteristic of bureaucracy would cause problems with the hierarchy which is too long because the bureaucracy has a great potential of Weber to cause pathology. Not only the issues of dysfunctional bureaucracy as the reason for the onset of a pathology of the bureaucracy but can also be caused by the bureaucratic apparatus and cultural behavior. For example, the nature of a familistic-localistic touched culture, social groups, tribes, became dominant in the practice of bureaucracy then it happens is who has access to which of the activities of the bureaucracy he will have ease, and who has access to a small then she is hard-pressed to get service. This condition will be exploited by unscrupulous rogue bureaucratic apparatus to do such undue 
undermines the Ministry, collusion, wild collection occurrence. Crozier $(2010$, p. 38) explains, there is the definite contrast between employee attitudes toward work and their job and their attitudes and behavior regarding of social participation within the organization. Patterns of behavior in the bureaucratic apparatus show will greatly affect the organization's social conditions, these conditions are to be kept in order to be impartial so that the image of the bad bureaucracy can be erased to slowly, and in the end the bureaucracy can be pliable and can be developed, due to the success of any organization who were the determinant of success is the people that exist therein. Goodsell (2004, p. 17) give explanations, other forms of client mistreatment stem from internal needs and drives of the "bureaucratic personality" (sometimes referred to as "bureaucratic mentality"). Sometimes the bureaucratic apparatus, feel they occupy the lowest position of the consequences they often delaying the job, shows pride, avoid excessively.

Caiden, 2009 (p. 112) mentions, the functional elements of bureaucracy, the specialization hierarchy, rules, production management direction, impersonality, and professionalization if overdone can eventually turn dysfunctional and unproductive. When the characteristics of bureaucracy reached the optimum point exceeds the performance, then the tendency of the performance will decrease and will lead to a dysfunctional bureaucracy, but when the performance level of the bureaucracy becomes excessive and beyond the point of optimal then the efficiency it will thus become increasingly weak. Caiden (2009) explained through the theory of curves-J or parabolic theory of bureaucracy, can be seen in the Figure 1.

Parabolic Theory of Bureaucracy valid on all the characteristics of bureaucracy Weber, Caiden gave his analysis based on the abundance of criticism, and there may be characteristics of the Weber will run well in different environmental conditions, and this was never explained by the Weber while giving his views about bureaucracy. We are always glued to the pathology of the bureaucracy's view only revolves around the structure, either a service hierarchy, corruption, long, dysfunctional, behavior of the bureaucratic apparatus. Caiden (1991) identified there are 178 pathologies that strike the body of bureaucracy, as in the Table 1 .

In fact, in practice the bureaucracy what Caiden above a large part of the case. As an example of corruption, at least by 2016 as many as 10 (ten) districts have been established by the KPK (Corruption Eradication Commission) as suspects of corruption. The most mode is the misuse of the budget, and the granting of permission for mining (Gabrillin, 2016). Bribery, this case is not something new for the bureaucracy, a crime that harms the

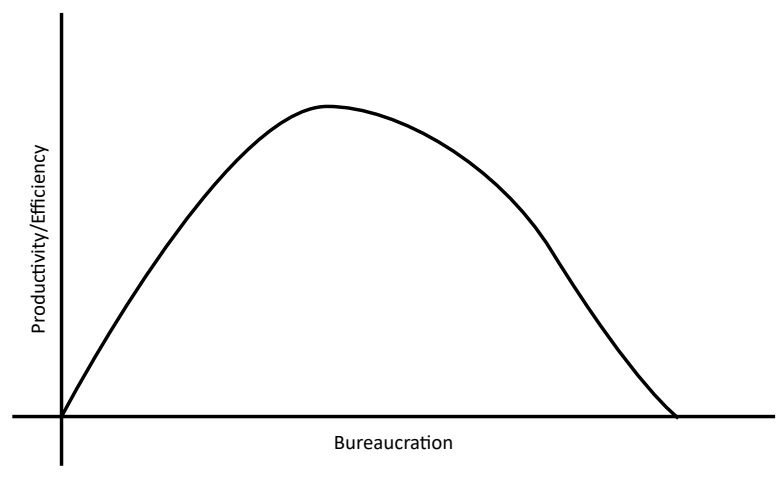

Figure 1. Parabolic Theory of Bureaucracy Source: Caiden (2009, p.112)

country involving elite government. Like the case of bribes one of the judges of the Constitutional Court (MK) the initials "PA" originating from the operation of hand capture by KPK (Fadil, 2017). Indiscipline, this case will be a lot going on during the holiday season. Real visible in various news media multitude of bureaucratic apparatus that does not comply with the provisions of entry work after long holidays.

Caiden (1991, p. 490) have reminded, ... but the systematic shortcomings of organizations that cause individuals within them to be guilty of malpractices. Not an individual problem, when doing wrong then the lack of organization that leads them to err. This lack of bureaucracy, therefore many countries racing to reform bureaucracy, bureaucratic innovation with all aspects only for problem-solving of the pathology of the bureaucracy's goal just puts a good service to the public provided by the bureaucracy.

\section{B. Preventive of Pathology Bureaucracy}

The phenomenon of the poor organization of the bureaucracy at the moment encourage the community to more crisis, caused by a bureaucracy that is unable to respond to the will of the people and resolve problems quickly. Resources and effort are made to think about the bureaucracy could function better in carrying out its duties, it is necessary a change of thinking on maintaining the old model which significantly nests from various diseases bureaucracy (Caiden, 1991; Bozeman, 2000). The change is not a change to the existing bureaucracy but rather how to make bureaucracy more flexible and evolve with new breakthrough makes something (innovation) which did not exist before, or develop existing ones become more effective longer which results in a good public service to create a good government governance as well. Many experts offers models and how to design an organization that leads not only the private sector but also the government's organization to make it more effective, depending on the usability and where the way it was placed, for example as 
Table 1.

Common Bureaupathologies

\begin{tabular}{|c|c|c|c|}
\hline \multicolumn{4}{|c|}{ Common Bureaupathologies } \\
\hline Abuse of authority/power/ & Fear of change, innovation, & Lack of creativity/ & Reluctance to delegate \\
\hline position & risk & experimentation & Reluctance to take \\
\hline Account padding & Finagling & Lack of credibility & decisions \\
\hline Alienation & Footdragging & Lack of imagination & Reluctance to take \\
\hline Anorexia & Framing & Lack of initiative & responsibility \\
\hline Arbitrariness & Fraud & Lack of performance & Remoteness \\
\hline Arrogance & Fudging/fuzzing (issues) & indicators & Rigidity/brittleness \\
\hline Bias & Gamesmanship & Lack of vision & Rip-offs \\
\hline Blurring issues & Gattopardismo & Lawlessness & Ritualism \\
\hline Boondoggles & (superficiality) & Laxity & Rudeness \\
\hline Bribery & Ghost employees & Leadership vacuums & Sabotage \\
\hline Bureaucratese & Gobbledygook/jargon & Malfeasance & Scams \\
\hline (unintelligibility) & Highhandedness & Malice & Secrecy \\
\hline Busywork & Ignorance & Malignity & Self-perpetuation \\
\hline Carelessness & Illegality & Meaningless/make work & Self-serving \\
\hline Chiseling & Impervious to criticism/ & Mediocrity & Slick bookkeeping \\
\hline Coercion & suggestion & Melanization & Sloppiness \\
\hline Complacency & Improper motivation & Mindless job performance & Social astigmatism (failure \\
\hline Compulsiveness & Inability to learn & Miscommunication & to see problems) \\
\hline Conflict of interest/ & Inaccessibility & Misconduct & Soul-destroying work \\
\hline objective & Inaction & Misfeasance & Spendthrift \\
\hline Confusion & Inadequate working & Misinformation & Spoils \\
\hline Conspiracy & conditions & Misplaced zeal & Stagnation \\
\hline Corruption & Inappropriateness & Negativism & Stalling \\
\hline Counter-productiveness & Incompatible task & Negligence/neglect & Stonewalling \\
\hline Cowardice & Incompetence & Nepotism & Suboptimization \\
\hline Criminality & Inconvenience & Neuroticism & Sycophancy \\
\hline Deadwood & Indecision (decidophobia) & Nonaccountability & Tail-chasing \\
\hline Deceit and deception & Indifference & Noncommunication & Tampering \\
\hline Dedication to status quo & Indiscipline & Nonfeasance & Territorial imperative \\
\hline Defective goods & Ineffectiveness & Nonproductivity & Theft \\
\hline Delay & Ineptitude & Obstruction & Tokenism \\
\hline Deterioration & Inertia & Officiousness & Tunnel vision \\
\hline Discourtesy & Inferior quality & Oppression & Unclear objectives \\
\hline Discrimination & Inflexibility & Overkill & Unfairness \\
\hline Diseconomies of size & Inhumanity & Oversight & Unnecessary work \\
\hline Displacement of goals/ & Injustice & Overspread & Unprofessional conduct \\
\hline objective & Insensitivity & Overstaffing & Unreasonableness \\
\hline Dogmatism & Insolence & Paper series & Unsafe conditions \\
\hline Dramaturgy & Intimidation & Paranoia & Unsuitable premises and \\
\hline Empire-building & Irregularity & Patronage & equipment \\
\hline Excessive social coast/ & Irrelevance & Payoffs and kickbacks & Usurpatory \\
\hline complexity & Irresolution & Perversity & Vanity \\
\hline Exploitation & Irresponsibility & Phony contract & Vested interest \\
\hline Extortion & Kleptocracy & Pointless activity & Vindictiveness \\
\hline Extravagance & Lack of commitment & Procrastination & Waste \\
\hline Failure to acknowledge/ & Lack of coordination & Punitive supervision & Whim \\
\hline act/answer/ & & Red-tape & Xenophobia \\
\hline response & & & \\
\hline Favoritism & & & \\
\hline
\end{tabular}

a model of Rational Model, Daft (2008); Denhardt \& Catlaw (2015); Star Model, Kates \& Galbraith (2007); Means-end Model, the Incremental Model, Pluralistic Model, Individual models, Rusaw (2007); Organization Learning, Maden (2011); Adhocracy, Toffler (1970); Mitnzberg (1993); Waterman, Jr. (1990); Hologram Organization, Mackenzie (1991). However, all models ever made can't be replaced the bureaucratic Weberian position of dominance and in the practice of the organization of the government especially on the part of developing countries and developed countries which until now still widely applied. The reason, Weber bureaucracy is a model of economic and social circumstances of the picture of a country (Sager \& Rosser, 2009). This description becomes the answer to the question, why study bureaucracy now? (Farazman, 2009).

A bureaucratic innovation appeared in the 
era of the 90s who became an idea to provide. As an example, when we want to climb the aircraft, the airline's party will certainly prepare its human resources ranging from technicians, pilots and flight attendants. With qualified human resources will be a major factor in flight safety, but on the other hand, the aircraft as a container for transporting passengers should have to innovate e.g. create seating which provides massage tools, multimedia, $\mathrm{Wi}-\mathrm{Fi}$ and others in serving and pampering passengers. Therefore, it must be immediately taken steps that are fundamental, systematic, and comprehensive, so that the goals and objectives that have been set can be achieved with effective bureaucratic performance and efficient bureaucracy, the performance includes a broader aspect than a just range in efficiency (Dwiyanto, 2015).

Innovation is seen not much needed for a government bureaucracy because faced with a variety of formal rules as a guideline that should not be violated. In fact, the private sector is more sensitive to the changes of the times and how to pamper customers consistently. The concept, known as the New Public Management, this concept is how to deliver good public service to the community by emulating the private principle grounded on organization performance, competitive market behavior (Hood, 1991; Osborne \& Gaebler, 1993; Lynn, 2006). This strategy was deemed necessary to respond to the old bureaucratic performance impressed the plodding, convoluted to cope with social changes and global changes as well. Answer these changes required new ideas to revamp the sluggish bureaucracy that had been impressed, convoluted in order to become faster, effectively innovate with the objective to maximize the potential of human resources a bureaucratic apparatus to create a culture of open and bureaucratic apparatus could be an agent of change, and encourage bureaucratic apparatus to further improve performance on an ongoing basis (Alberti \& Bertucci, 2007). The idea of Innovation is also set in the legislation of the Republic of Indonesia Number 23 by 2014 about local government in section 386 paragraph 1.

\section{1) Aspects of Innovation}

The various efforts were undertaken by the government to first settle for giving a good public service. Innovation process involves several elements in the organization as the seeds that would blossom into innovation and is a cycle of innovation process (Gajduschek, 2003; Veenswijk, 2005; Styhre, 2007; OECD, 2011; Hummel, 2015; McLaughlin \& Kennedy, 2016). Zahn \& Weidler (1995) as cited Sauber \& Tschirky (2006, p. 33) elements of innovation at the organizational level, based on the structure, systems, and culture that are an inseparable part of doing innovation. The structure, if innovation leads to changing organizational structure then the direction towards how the behavior of an organization when the structure changed if more effective or not. The system, the number of cheating that occurs in a bureaucratic practice (collusion, corruption, nepotism) became a serious thought for the government, so the government is doing the bureaucratic reform movement to resolve the problems in the practice of the bureaucracy, the goal only to convening the government with improving the principle of good government and good governance. The government started doing breakthrough work on systems such as the implementation of the activities of the electronic-based government (e-government).

Culture, Herbig \& Dunphy (1998, p. 15) say, culture has a profound influence on the innovative

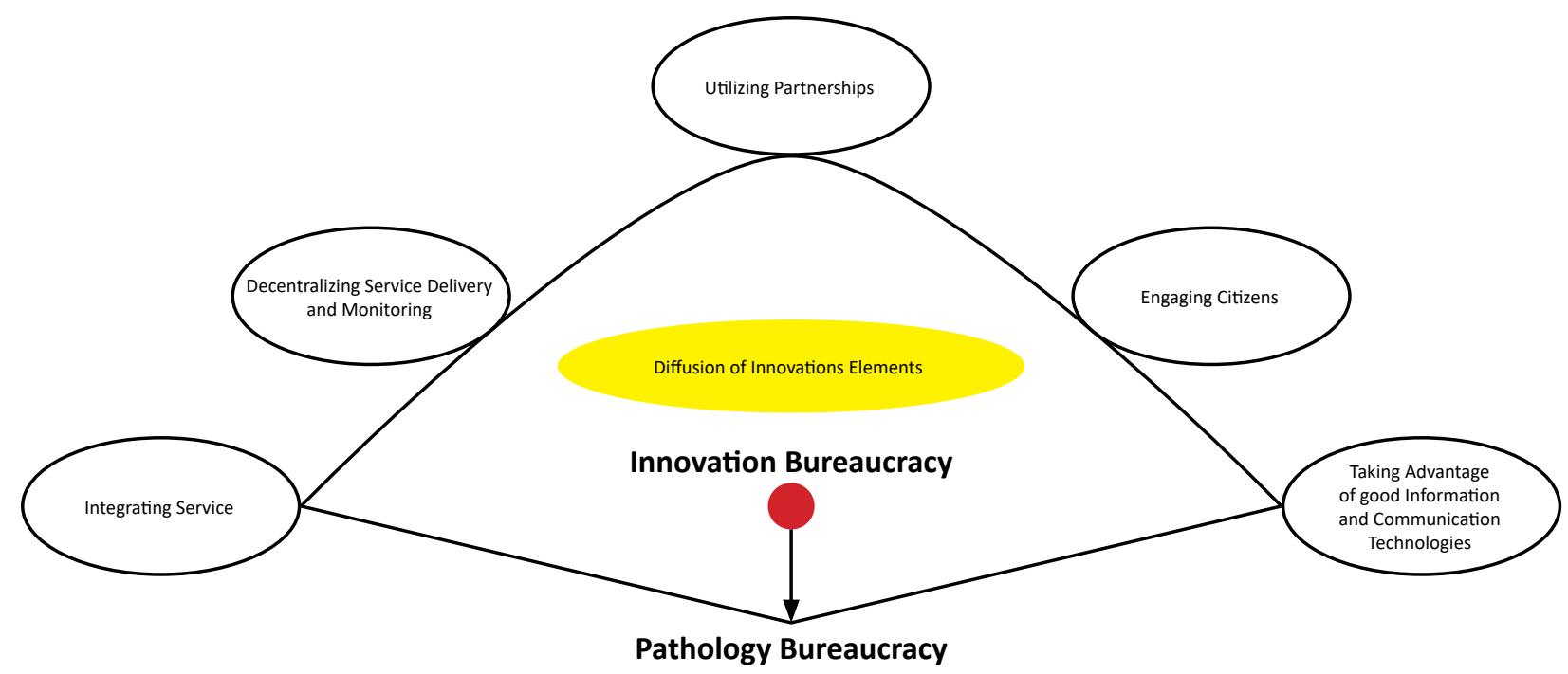

Figure 2. Innovation Bureaucracy Process

Source: Elaborate by author, based on Alberti \& Bertucci (2007); (Rogers, 1995) 
capacity of a society. Culture is not just talking about something the entity attached to individual or group that will affect the continuity of the performance of the bureaucracy. Culture is the unique thing will cause values to the individual such as action, belief, behavior. A culture of innovation in your organization will appear when all individuals are given the opportunity to find new ways that are more efficient on a consistent basis that goes beyond the limits of ability they have (Horibe, 2001; Zennouche, Zhang, \& Wang, 2014).

\section{2) Innovation Bureaucracy as Government}

Ven de Ven \& Pole (2000, p. 32) argue, while innovation is defined as the introduction of a new idea, the process of innovation refers to the temporal sequence of events that occur on u.s. Browse national interact with others to develop and implement their innovation ideas within an institutional context. On the organization of the government needed new thinking to parse a chronic disease which has always been a source of problems in delivering public services. Alberti \& Bertucci $(2007$, p. 8) give it a there are five primary strategies of government innovation, 1). Integrating Services; 2.) Decentralizing Service Delivery and Monitoring; 3) Utilizing Partnerships; 4). Engaging Citizens; 5). Taking Advantage of Information and Communication Technologies. As illustrated in Figure 2.

\section{a) Integrating Service;}

The concept of public service offers a quality service not only the provision of the service but how communities get these services efficiently and comfortably so that the alignment between hope and reality become balanced. Shah, (2005, p. xxiii) argue, traditionally, public trust in public sector performance in delivering services consistent with citizen preferences has been considered weak in developing countries. In developing countries, this opinion seems right presence such as Indonesia, the number of cases of corruption of officials is an indication of poor corporate governance of a good government. The politicians and bureaucrats will likely be having an affair for the sake of seeking personal gain from the groupings and on should think of how to pamper their citizens by providing good service, although been a lot done we should hope for more.

b) Decentralizing Service Delivery and Monitoring;

Decentralization of services pushed economic development recently outside of urban centers, increasing public participation and increased trust in government (Alberti \& Bertucci, 2007).

c) Utilizing Partnerships;

Service cooperation with the private sector to promote efficiency and quality of service on the government as the local media television, local radio, shared service development also conduct educational institutions for conducts ongoing research.

d) Engaging Citizens;

When the Government provides a forum for the public to express their views and be involved in all processes of innovation are more likely to succeed and spread (Alberti \& Bertucci, 2007). For example, in developing countries like Africa community participation is very limited especially for the reason of the poor because the poor are less contributed in organizing the government. Events in Latin America countries, public participation is not always the most important thing to create a good government governance wrapped decentralized government in the Middle East, allowing public participation does not mean they will push more actively for real public participation in supervising community. Cheema \& Rondinelli (2007, p. 9) explains decentralization and citizen participation are conditioned by complex political, historical, social, and economic factors that differ in strength and importance among and within countries. Factor in political, social and economic history that affect the participation of the community in a country. Although public participation is being argued on the bright side make citizens more meaningful for the country, so the country is responsible for delivering good service to the community (Callahan, 2007).

e) Taking Advantage of good Information and Communication Technologies.

The use of internet-based services or e-government aims to be a simple administrative process so that, contribute to the citizens in obtaining information and increase transparency and integrity in public administration. Kushchu \& Kuscu (2003, p. 2) have argued, the meaning of electronic-based governance, strategy and its implementation involving the utilization ... for improving benefits to the parties involved in e-government including citizens, businesses, and all 
government units. The explanation this give you an idea to us, using all kinds of technology will increase the benefits to the parties involved in e-government including citizens, the business sectors, and government institutions as well. It looks like e-government will be very difficult to apply to poor areas because it requires a huge budget. Then comes the expectations by utilizing smartphone applications with low cost. What is mobile government can replace the e-government? Ghyasi \& Kushchu (2004) and Kushchu (2007) reply, the existence of mobile government, can't instead of e-government, but the application of mobile government is the implementation of e-government, in certain cases the existence of mobile government supports some of the activities of the government.

Innovation in their implementation requires the control to explain how big can be applied, and how long it takes. To explain innovation, the way that is often used is the diffusion elements and innovations. Rogers (1995, p. 10), 1). Innovations; 2). Communication Channels; 3) Time; 4) Social System. Development of innovation not only aims to unravel the problem that can't be described by conventional models but innovation also requires new thinking, to create something new or develop existing things into more effective longer. To see how big, the rate of implementation of innovation can be measured as Figure 3 .

Description of the view of the diffusion and innovations can be described as the main concept of innovation:

- Innovations:

Innovation is the idea and the practice of an objective that is considered new, resized by a certain time, the novelty considered an idea. Innovation not only involves a knowledge attitude, but the behavior in innovation is important, whether beneficial or detrimental instead. The bureaucracy must always be evolving towards improvements not only in restructuring, rules, quality of work, career patterns. Profit in may was relatively better than instead of those that already exist, some innovations will easily have understood and absorbed quickly from on some innovations that are complicated but slow to implement.

- Communication Channels;

This section is a description of diffusion that is mentioned earlier, process submission of the mind or feelings by a person to another person, the point is the exchange of information about new ideas from one individual to another

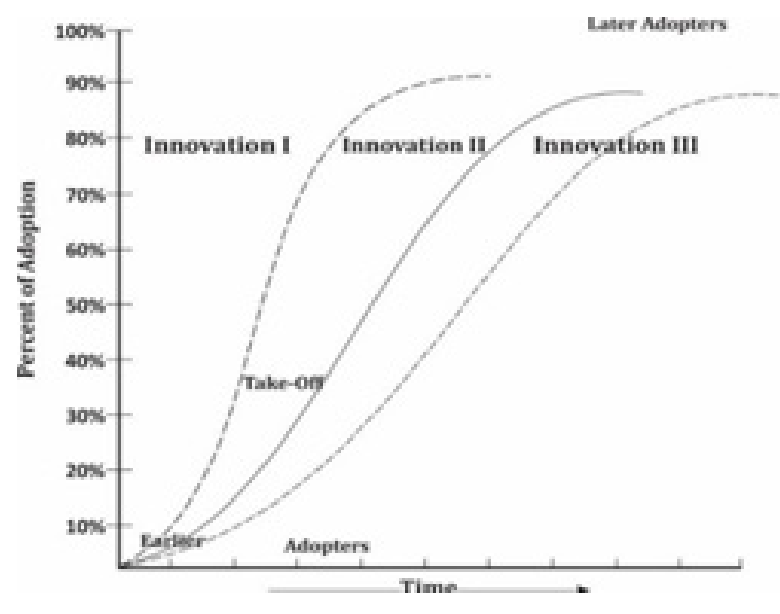

Figure 3. Diffusion and Innovations Elements Source: Rogers (1995, p.11)

individual that is of mutual benefit in sharing information. Griffin, (2012, p.6) argue, communication is the relational process of creating and interpreting messages that elicit a response. Communications act to control behavior, create and understanding messages that bring in response to someone. The usefulness of communication is so connected with the surrounding environment.

- Time;

Time is an essential element to providing information, the time will not be detached from the events, but time is an aspect of every activity. Time will also clarify the targets to be achieved, the extent to which time was taken can trim the budget and distance, time and effort.

- Social System.

Rogers (1995, p. 23) back to explain, a social system is defined as a set of interrelated units that are engaged in joint problemsolving to accomplish a common goal. A social system is a unit linked in problem-solving to achieve a common goal, it is possible that it is a social system of individuals, informal groups, organizations, or even the subsystem. The whole of the social elements that are associated and connected, influencing together in one unit. Perform the function of social system integrity by generating solidarity and togetherness, determine the action that is acceptable or unacceptable, a social system consists of various interactions change the values and norms of social institutions (Ritzer, 2005).

Make something more effective than needed a surefire strategy to do so. Keys to successful strategy requires the existence of, goals that a simple, 
consistent, and long-term, profound understanding of the competitive environment, objective appraisal of resources (Grant \& Jordan, 2015).

\section{3) Innovation Bureaucracy Conceptual}

McLaughlin \& Kennedy (2016, p. 4) argue, innovation, as an agency or organizational goals, seems to be a reasonable objective. Innovation is not something defined, too simple when saying that innovation is the discovery of new ideas, real innovation has 60 defined (Baregheh, Rowley, \& Sambrook, 2009). Innovation always starts with understanding will new ways and is always associated with the utilization of technology (McLaughlin \& Kennedy, 2016; Gobble, 2016). Then the rational choices will be selected, starting from the simple yet rich innovation benefits. Agger \& Sorensen (2016, p. 3) give arguments a phenomenon needs only to be new in the context in which it is implemented to count as an innovation. It should be emphasized that innovation is not always a good thing. Innovation is not just telling you about the solution of some evil practices in implementing countries, do not always tell you about conjures up creative ideas but how innovation can be built on an ongoing basis starting from a basic understanding of innovation.

Not only the organizations need to innovate, but human resources (ASN) also need to develop the creativity of individuals to be able to contribute to national development with a contribution of thought and creativity (innovation). For example, Malaysia gives discretion to the state apparatus to cultivate creativity in individuals and teams through a national project to develop and implement each of the government policies by generating a range of innovative products but cheaper costs (BKN, 2016). How simple can be done in various ways such as providing incentives for bureaucratic apparatus that can find new ideas that are rational, provide adequate support facilities as a comparison we will see private giving vastness at the research, then they will try to convince the leadership that what they do is useful and has added value, so that funds will be available. But Veenswijk (2005) gives an overview, to do research on the government need not have to go through the research section, but get used and give breadth to the bureaucratic apparatus to bring up the idea, his creativity and is a process to create a culture of innovation.

Innovation can be a discovery and invention. The discovery of something that already exists but it is not yet known isn't just about new things (invention) but developed something that already is becoming more efficient longer. In contrast to the bureaucracy, innovation is considered not so necessary that still upholds the hierarchy, rules, and procedures that became part of the lack of bureaucracy. Klareskov \& Nikolov (2007, p. 44) asserted, innovations in traditional bureaucracies once thought of us solutions to problems such as nepotism, patronage, and cronyism. Innovation can be the solution for the evil practice in bureaucracy including corruption, collusion, nepotism. Therefore, it must be immediately taken steps that are fundamental, systematic, and comprehensive so that the goals and objectives that have been set by the performance of the bureaucracy that is effective and efficient. The performance of the bureaucracy includes the broader aspect than on the only range in efficiency. Sometimes some parties will see an apathetic innovation-minded government that is just using a large state budget. A wide variety of conceptual thought served with rich in the scientific literature with the approach and focus vary, the point is just to make the bureaucracy more realistic, and doing its job well. To understand these innovations can be seen in Figure 4.

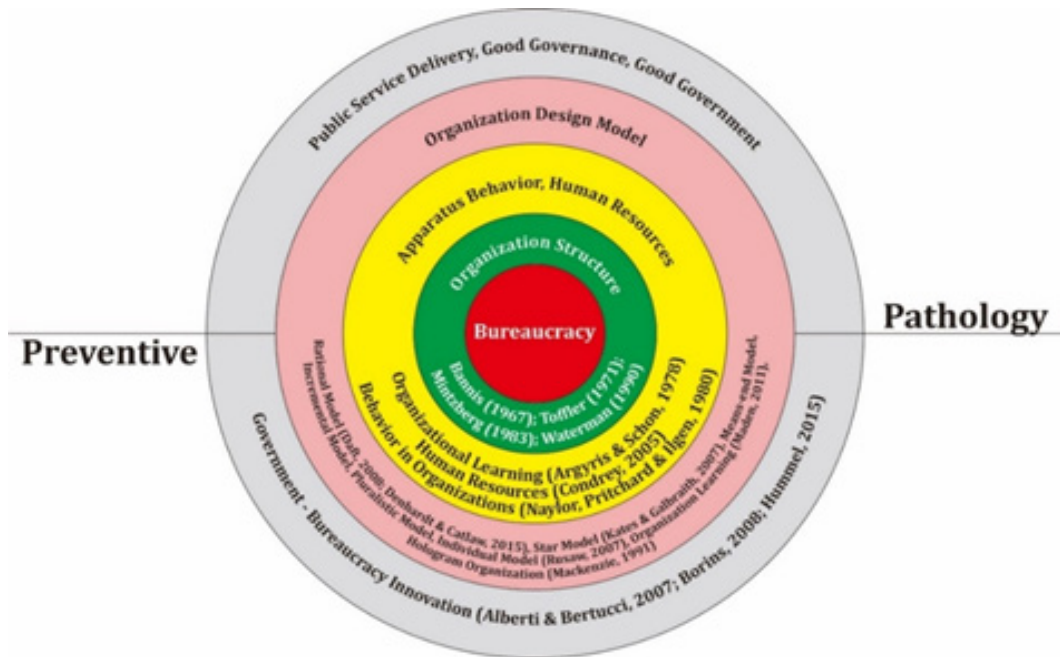

Figure 4. Conceptual Innovations Source: Elaborate by author 
Innovation in government activities is becoming a must for countries that want to keep the opportunities and challenges to face the problems of a society that is so complex (Alberti \& Bertucci, 2007). Innovation rooted in knowledge to answer any question, especially on government organization (bureaucracy) to restore public confidence, delivering good public services. If would like to make changes not only driven by a set of rules as a guideline but the most important role of a leader. Tahrima \& Jaegal (2012, p. 143) provide an explanation, successful innovation requires leadership to establish the organizational capacity to generate ideas and to ensure prompt and effective service. Leadership can be a facilitator of change the bureaucracy and government facilities become the catalyst to compete, efficiency and productivity to perform a wide range of innovations. These activities will only run if the initial process of placing one's leadership carried out correctly, by the capacity and the knowledge that he had and did a variety of formal and informal education is often done by the government. Many occur in local government appointment "head of agency" practice selling terms (the case of Klaten Regency). On the other hand, for those leaders who do not want to make changes to the same meaning that they tarnish the country's goals written in the preamble of the Constitution of the Republic of Indonesia in 1945 on paragraph 4 and provide opportunities for bureaucratic pathology thrives.

Various views we can examine how efforts are being made to cover up the lack of bureaucracy. For example, when the source of the pathology of the bureaucracy comes from the structure of the organization then it can be prevented by using the view adhocracy or ad-hoc. This design was the model that was created outside bureaucratic structure that we know, more to make models that are not bound by bureaucratic characteristics such as Weber and delivered only responsible to the results.

\section{Conclusion}

The bureaucracy that does not open up with the development of the surrounding environment will make this organization seen as government organizations that will meet his end, as an unhealthy bureaucracy became the site of the nest of the disease (pathology) bureaucracy to proliferate. This condition will endanger the government, and the public will not believe anymore with the service provided, in the long term it will force communities do not have the option to use private sector services. The various efforts were taken by the government to present a good public service to the community. Innovation is a way of the many ways to give change in the bureaucracy. Bring something new or make existing ones effective again, innovation becomes the main menu when the society began to critically. The country needs, providing service to society as well, though the society of a country not fully critical democratic and good service is mandatory.

\section{A. Suggestions}

Suggestions/recommendations as the core to contribute thoughts to recognize the pathology of the bureaucracy and the way of prevention:

1. Innovation became one of the sustainable solutions;

2. Innovation gives the space of creativity by growing a culture of innovation, leadership can be a facilitator and motivator;

3. Doing the competition with prizes for the bureaucratic apparatus that is capable of finding simple but rich in benefits while giving stimulus to cultivate the seeds of creativity to new or develop existing ones based on originality without imitating the work of others;

4. When the budget is limited, in applicative can make use of mobile government with cheap cost but rich in benefits;

5. The placement of a person to occupy the position should be properly put forward the merit system and away from the principle of collusion and nepotism;

6. As a basis for conducting discretion policy for local authorities to improve the performance of the bureaucracy;

7. Engender and nurture a culture of innovation to reform the bureaucracy supporting the year 2025.

\section{REFERENCES}

Ackerman, S. R. (1999). Corruption and Government Causes, Consequences, and Reform. Cambridge: Cambridge University Press.

Agger, A., \& Sorensen, E. (2016). Managing Collaborative Innovation in Public Bureaucracies. Planning Theory, 1-21. doi:10.1177/1473095216672500

Alberti, A., \& Bertucci, G. (2007). Innovation in Governance and Public Administration: Key Issues and Perspectives. In D. o. Affairs, Innovations in Governance in the Middle East, North Africa, and Western Balkans: Making Governments Work Better in the Mediterranean Region (pp. 3-12). New York: United Nations.

Albrow, M. (2005). Birokrasi. (Alih Bahasa, M. R. Karim, \& T. Daryanto) Yogyakarta: Tiara Wacana.

Alkatib, H. (2013). E-Government Systems Success and User Acceptance in Developing Countries: The Role of Perceived Support Quality. A 
Thesis Submitted for the Degree of Doctor of Philosophy, Brunel University, London.

AlQahtani, K. M. (2013). Investigating The Impact of Bureaucractic Factors on Government Organisational Performance in The Kingdom of Bahrain: A Multiple Case Study Approach. Thesis Submitted For The Degree of Doctor of Philosophy, Brunel University, London, UK.

Amadi, L., \& Ekekwe, E. (2014). Corruption and Development Administration in Africa: Institutional Approach. African Journal of Political Science and International Releations, 8(6), 163-174. doi:10.5897/AJPSIR2013.0634

Argyriades, D. (2010). From Bureaucracy to Debureaucratization? Public Organiz Rev, 10, 275-297. doi:http://dx.doi.org/10.1007/ s11115-010-0136-1

Baregheh, A., Rowley, J., \& Sambrook, S. (2009). Towards a Multidisciplinary Defenition of Innovation. Management Decision, 47(8), 13231339. doi:10.1108/00251740910984578

Bendor, J. (2010). Bounded Rationality and Politics. California: University of California Press.

BKN, T. B. (2016). Buletin Badan Kepegawaian Negara Informasi Yang Mencerahkan Edisi XXXVI.

Bozeman, B. (2000). Bureaucracy and Red Tape. New Jersey: Prentice Hall.

Brewer, G. A., \& Walker, R. M. (2010). The Impact of Red Tape on Governmental Performance: An Empical Analysis. Journal of Public Administration Research and Theory, 20(1), 233-257. Retrieved from http://www.jstor. org/stable/20627900

Budd, L. (2007). Post-Bureaucracy and Reanimating Public Governance A Discourse and Practice of Continuity? International Journal of Public Sector Management, 20(6), 531-547. doi:10.1108/09513550710818403

Caiden, G. E. (1991). What Really Is Public Maladministration? Public Administration Review, 51(6), 486-493. Retrieved from http:// www.jstor.org/stable/976599

------------(2009). A Parabolic Theory of Bureaucracy or Max Weber through the Looking Glass. In A. Farazman, Bureaucracy and Administration (p. 111). Florida: CRC Press.

Callahan, K. (2007). Elements of Effective Governance: Measurement, Accountability and Participation. Boca Raton, FL: Taylor \& Francis Group.

Cheema, G. S., \& Rondinelli, D. A. (2007). Decentralizing Governance: Emerging Concept and Practice. Washington D.C: Brookings Institution Press.

Clegg, S. R. (1997). Modern Organizations: Organization Studies in The Postmodern Word.
London: SAGE Publications.

Crozier, M. (2010). The Bureaucratic Phenomenon. New Jersey: Transaction Publishers.

Daft, R. L. (2008). Organization Theory and Design (10th ed.). Boston: Cengage Learning.

Denhardt, R. B., \& Catlaw, T. J. (2015). Theories of Public Organization (7th ed.). Stamford: Cengage Learning.

Diefenbach, T., \& Todnem, R. (2012). Bureaucracy and Hierarchy - What Else!? In T. Diefenbach, \& R. Todnem, Research in the Sociology of Organizations Bureau to Network Organizations Volume 35 (pp. 1-27). Bradford: Emerald Group Publishing Limited.

Dwiyanto, A. (2015). Reformasi Birokrasi Kontekstual. Yogyakarta: Gadjah Mada University Press.

Eyre, C. (2011). Patronage, Power, and Corruption in Pharaonic Egypt. International Journal of Public Administration, 34(11), 701-711. doi: http://dx.doi.org/10.1080/01900692.2011.5 98286

Fadhil, H. (2017, Januari 26). OTT Patrialis Akbar, KPK: Ada 11 Orang yang Ditangkap. Retrieved from detikNews: https://news.detik.com/ berita/d-3406283/ott-patrialis-akbar-kpkada-11-orang-yang-ditangkap

Farazman, A. (2009). Bureaucracy and Administration. Boca Raton: CRC Press.

Gabrillin, A. (2016, 12 12). Kaleidoskop 2016: 10 Kepala Daerah Tersangka Korupsi. Retrieved from Kompas.com: http://nasional.kompas. c o m / r ead / 2016 / 12 / 12 / 09232571 / kaleidoskop.2016.10.kepala.daerah.tersangka. korupsi.?page $=$ all

Gailmard, S., \& Patty, J. W. (2012). Formal Models of Bureaucracy. Annual Review of Political Science, 15, 353-377. doi:https://doi.org/10.1146/ annurev-polisci-031710-103314

Gajduschek, G. (2003). Bureaucracy: is it Efficient? is it Not? is That Question? Administration \& Society, 34(6), 700-723. doi:10.1177/0095399702239171

Garston, N. (1993). Bureaucracy: Three Paradigms. New York: Springer Science+Business Media.

Ghyasi, A. F., \& Kushchu, I. (2004, Mei). m-Government: Cases of Developing Countries. Retrieved from Mobile Government Lab (mGovLab): http://www.mgovlab.org

Gobble, M. M. (2016). How Government Innovates. Research-Technology Management, 59(2), 6267. doi: http://dx.doi.org/10.1080/08956308 .2015 .1137188

Goodsell, C. T. (2004). The Case for Bureaucracy: A Public Administration Polemic (4th ed.). Washington, D.C: CQ Press.

-(2015). New Case Bureaucracy. Washington, DC: CQ Press. 
Gough, D., Oliver, S., \& Thomas, J. (2012). An Introduction to Systematic Reviews. London: SAGE Publications.

Grant, R. M., \& Jordan, J. (2015). Foundations of Strategy (2nd ed.). West Sussex: John Wiley \& Sons Ltd.

Griffin, E. (2012). A Firts Look at Communication Theory (8th ed.). New York: McGraw-Hill.

Herbig, P., \& Dunphy, S. (1998). Culture and Innovation. Cross Cultural Management: An International Journal, 5(4), 13-21. doi:http:// dx.doi.org/10.1108/13527609810796844

Hood, C. (1991). A Public Management For All Seasons ? Public Administration, 69, 3-19. doi:10.1111/j.1467-9299.1991.tb00779.x

Horibe, F. (2001). Creating the Innovation Culture : Leveraging Visionaries, Dissenters and Other Useful Troublemakers in Your Organization. Ontario: John Wiley \& Sons Canada Limited.

Hummel, R. P. (2015). The Bureaucractic Experience: The Post Modern Challenge (5th ed.). Oxon: Routledge.

IGI. (2016, Oktober 24). What is Administrative Reform. Retrieved from IGI Global Disseminator of Knowledge: http://www.igi-global.com/ dictionary/administrative-reform/681

Jesson, J. K., Matheson, L., \& Lacey, F. M. (2011). Doing Your Literature Review: Traditional and Systematic Techniques. London: SAGE Publications.

Johnston, K. (1993). Busting Bureaucracy How to Conquer Your Organization's Worst Enemy. Illionis: R. R. Donnelley \& Sons Company.

Kates, A., \& Galbraith, J. R. (2007). Designing Your Organization Using the Star Model to Solve 5 Critical Design Challenges. San Francisco: Jossey-Bass A Wiley Imprint.

Kemendagri. (2016, April 25). Peringatan Hari Otda 2016, Kemendagri Beri Penghargaan Sejumlah Pemda. Retrieved from Kementrian Dalam Negeri: http://www.kemendagri. go.id/news/2016/04/25/peringatan-hariotda-2016-kemendagri-beri-penghargaansejumlah-pemda

Kemenpan, R. (2016, September 25). Hasil Evaluasi Pelaksanaan Reformasi Birokrasi, Akuntabilitas dan Zona Integritas. Retrieved from Kementrian Pendayagunaan Aparatur Negara dan Reformasi Birokrasi: http:// evalrbkunwas.menpan.go.id/index.php/site/ kabupaten

Kernaghan, K. (2000). The Post-Bureaucratic Organization and Public Service Values. International Review of Administrative Sciences, 66(2000), 91-104. doi: https://doi. org/10.1177/0020852300661008

Klareskov, V., \& Nikolov, D. (2007). Eleven Innovations in Governance in the Middle East,
North Africa, and Western Balkans: A Synopsis. In D. o. Affairs, Innovations in Governance in the Middle East, North Africa, and Western Balkans: Making Governments Work Better in the Mediterranean Region (pp. 41-52). New York: United Nations.

Kushchu, I. (2007). Mobile Government: An Emerging Direction in E-Government. Hershey PA: IGI Publishing.

Kushchu, I., \& Kuscu, M. H. (2003). From E-government to M-government: Facing the Inevitable. Proceeding of European Conference on E-Government (ECEG 2003) Trinity College (pp. 253-260). Dublin: Reading UK Academic Conferences International.

Lynn, J. L. (2006). Public Management Old and New. New York: Routledge.

Mackenzie, K. D. (1991). The Organizational Hologram: The Effective Management of Organizational Change. New York: Springer Seience+Business Media.

Maden,C.(2012). Transforming Public Organizations into Learning Organizations: A Conceptual Model. Public Organization Review, 12, 71-84. doi:10.1007/s11115-011-0160-9

Mayo, S. (2014). Corruption in Zimbabwe An Examination of the Roles of the State and Civil Society in Combating Corruption. A thesis submitted in partial fulfilment for the requirements for the degree of Doctor of Philosophy, University of Central Lancashire, England.

McLaughlin, G. C., \& Kennedy, W. R. (2016). A Guide to Innovation Processes and Solutions for Government. Boca Raton, FL: CRC Press.

Mill, J. S. (2001). Considerations on Representative Government. London: The Electric Book Company Ltd .

Mintzberg, H. (1993). Structure in Five Designing Effective Organizations. New Jersey: PrenticeHall.

Niskanen, J. W. (2007). Bureaucracy and Representative Government. New Jersey: AldineTransaction.

OECD. (2011). The Call for Innovative and Open Government An Overview of Country Initiatives. OECD Publications.

OmbudsmanRI. (2016). Laporan Statistik. Retrieved from Ombudsman Republik Indonesia: http:// www.ombudsman.go.id/index.php/laporan/ laporan-statistik.html

Osborne, D., \& Gaebler, T. (1993). Reiventing Government How The Enterpreneurial Spirit is Transforming the Public Sector (10th ed.). Boston: Addison-Wesley Publishing Company.

Parker, R., \& Bradley, L. (2004). Bureaucracy or Post-Bureaucracy? Public Sector Organisations in a Changing Context. The Asia Pasific Jornal 
of Public Administration, 26(2), 197-215. doi:https://doi.org/10.1080/23276665.2004. 10779293

Petticrew, M., \& Roberts, H. (2009). Systematic Reviews in the Social Sciences: An Practical Guide. Malden, MA: Blackwell Publishing.

Pierre, J. (1995). Bureaucracy in the Modem State: Introduction to Comparative Public Administration. Cheltenham: Edward Elgar Publishing Limited.

Pinho, J. A., \& Sacramento, A. R. (2015). Brazil: Between the Modern Bureaucracy of Weber and Resilient Patrimonialism. Management Research: The Journal of the Iberoamerican Academy of Management, 13(2), 140-159. doi: 10.1108/MRJIAM-04-2014-0548

Presthus, R. V. (1961). Weberian vs Welfare Bureaucracy in Traditional Society. Administrative Science Quarterly, 6(1), 1-24. Retrieved from http://www.jstor.org/ stable/2390738

Ritzer, G. (2005). Encyclopedia of Social Theory (Vol. I). Thousand Oaks: Sage Publications.

Rogers, E. M. (1995). Diffusion of Innovations (4th ed.). New York: The Free Press.

Rusaw, A. C. (2007). Changing Public Organizations: Four Approaches. International Journal of Public Administration, 30(3), 347-361. doi:10.1080/01900690601117853

Sager, F., \& Rosser, C. (2009). Weber, Wilson, and Hegel: Theories of Modern Bureaucracy. Public Administration Review, 1136-1147. doi:10.1111/j.1540-6210.2009.02071.x

Sauber, T., \& Tschirky, H. (2009). Structured Creativity Formulating an Innovation Strategy. New York, NY: Palgrave Macmillan.

Shah, A. (2005). Public Service Delivery. Washington D.C: The World Bank.

Shi, S., \& Temzelides, T. (2004). A Model of Bureaucracy and Corruption. International Economic Review, 45(3), 873-908. Retrieved from https://www.economics.utoronto. ca / public/working Papers / U T-ECIPASHOUYONG-03-02.pdf

Simon, H. A. (2007). Administrative Behavior:
A Study of Decision Making Processes in Administrative Organizations (4th ed.). New York: The Free Press.

Styhre, A. (2007). The Innovative Bureaucracy: Bureaucracy in an of Fluidity. New York: Routledge.

Tahmer, A. (2013). Reformasi Birokrasi Pada Pemerintah Daerah Provinsi Banten. Disertasi, Universitas Padjadjaran, Bandung.

Tahrima, S., \& Jaegal, D. (2012). Challenges for Government Innovation in Bangladesh. The Korean Journal of Policy Studies, 27(2), 143173.

Toffler, A. (1971). The Future Shock (15 th ed.). New York: Bantam Book.

Tolbert, P. S. (2010, May 04). Robert Michels and the Iron Law of Oligarchy. Retrieved from Cornell University, ILR School: http://digitalcommons. ilr.cornell.edu/articles/397/

Torgerson, C. (2003). Systematic Reviews. London: Continum International Publishing Group.

Veenswijk, M. (2005). Cultural Change in the Public Sector: Innovating the Frontstage and Backstage. In M. Veenswijk, Organizing Innovation New Approaches to Cultural Change and Intervention in Public Sector Organizations (pp. 3-14). Amsterdam: IOS Press.

Ven de Ven, A. A., \& Pole, M. S. (2000). Methods for Studying Innovation Processes. In A. A. Ven de Ven, L. Herold, \& M. S. Pole, Research on the Management of Innovation (pp. 31-54). Oxford: Oxford University Press.

Waterman, R. J. (1990). Adhocracy The Power of Change. Knoxville: Whittle Direct Books.

Zennouche, M., Zhang, J., \& Wang, B. W. (2014). Factors Influencing Innovation at Individual, Group and Organisational Levels: A Content Analysis. International Journal Information Systems and Change Management, 7(1), 23-42. doi: http://dx.doi.org/10.1504/ IJISCM.2014.065052

Constitution of the Republic of Indonesia of 1945.

Law of the Republic of Indonesia Number 23 of 2014 on Regional Administration., Pub. L. No. 23 (2014). Indonesia. 